\title{
Gambaran kadar kolesterol total darah pada pekerja kantor
}

\author{
${ }^{1}$ Oktavia T. Waani \\ ${ }^{2}$ Murniati Tiho \\ ${ }^{2}$ Stefana H.M. Kaligis
}

\author{
${ }^{1}$ Kandidat Skripsi Fakultas Kedokteran Universitas Sam Ratulangi Manado \\ ${ }^{2}$ Bagian Biokimia Fakultas Kedokteran Universitas Sam Ratulangi Manado \\ Email: theaoktaviawaani@yahoo.co.id
}

\begin{abstract}
Cholesterol is a major component of brain and nerve cells and also as the resources for a number of important compunds in the body. The intensity of a person's activity affect the levels of cholesterol in the body. Physical inactivity is one of the risk factors for lipid accumulation in the body which can cause a strain in the heart and blood vessels. This study aimed to determine the total cholesterol levels in office workers. The design of this study was a descriptive analysis with a cross sectional study. Samples were 52 people taken with total sampling method. The result showed the respondents with normal cholesterol levels were the same number as respondents with high cholesterol levels $(50,00 \% ; 26$ people). The mean cholesterol levels of 52 samples was $198 \mathrm{mg} / \mathrm{dL}$, the median was $201 \mathrm{mg} / \mathrm{dL}$, the modus was $214 \mathrm{mg} / \mathrm{dL}$, the minimal dan maximal were $143 \mathrm{mg} / \mathrm{dL}$ and $273 \mathrm{mg} / \mathrm{dL}$, and the strandard deviation was 29,22. Conclusion: The number of respondents with normal cholesterol levels and with high cholesterol levels are equal.
\end{abstract}

Keywords: the total cholesterol levels, office workers

\begin{abstract}
Abstrak: Kolesterol merupakan komponen utama sel otak dan saraf, serta merupakan bahan pembentuk sejumlah senyawa penting dalam tubuh. Intensitas akivitas seseorang berpengaruh terhadap kadar kolesterol dalam tubuh. Kurangnya aktivitas fisik merupakan salah satu faktor risiko penumpukan lipid dalam tubuh sehingga yang dapat menyebabkan gangguan pada jantung dan pembuluh darah. Tujuan dari penelitian ini adalah untuk mengetahui gambaran kadar kolesterol total darah pada pekerja kantor. Penelitian yang digunakan bersifat deskriptif dengan pendekatan cross sectional. Sampel dalam penelitian ini berjumlah 52 orang yang sesuai kriteria inklusi dan bersedia menjadi responden. Metode pemilihan sampel menggunakan cara total sampling. Hasil penelitian responden dengan kadar kolesterol normal $(<200 \mathrm{mg} / \mathrm{dL})$ dan responden dengan kadar kolesterol tinggi memiliki jumlah responden yang seimbang yaitu sebanyak 26 orang $(50,00 \%)$. Nilai rata-rata yaitu $198 \mathrm{mg} / \mathrm{dL}$, nilai median $201 \mathrm{mg} / \mathrm{dL}$, nilai modus $214 \mathrm{mg} / \mathrm{dL}$, nilai minimal 143 $\mathrm{mg} / \mathrm{dL}$, nilai maksimal $273 \mathrm{mg} / \mathrm{dL}$, dan standar deviasi 29,22. Simpulan: Jumlah antara responden dengan kadar kolesterol darah normal dengan kadar kolesterol darah tinggi adalah seimbang.
\end{abstract}

Kata kunci: kadar kolesterol total darah, pekerja kantor.

Penyakit jantung dan pembuluh darah menurut data dari World Health Organization (WHO), pada tahun 2012 menyebabkan sekitar 17,5 juta atau setara dengan $31 \%$ kematian di seluruh dunia. Dari angka kematian diatas diperkirakan
7,4 juta disebabkan oleh Penyakit Jantung Koroner (PJK) dan 6,7 juta disebabkan karena penyakit stroke. ${ }^{1}$

Di Amerika Serikat setiap tahun 550.000 orang meninggal karena gangguan pada jantung. Di Eropa menurut data yang 
diambil pada tahun 2012, penyakit Jantung Koroner merupakan penyebab utama kematian sekitar 4 juta kematian dalam setiap tahunnya. Dalam beberapa tahun terakhir hampir setengah dari jumlah kematian (sekitar 47\%) dari seluruh jumlah kematian disebabkan oleh PJK (52\% pada wanita dan $42 \%$ pada pria). ${ }^{2}$

Berdasarkan diagnosis dokter, prevalensi penyakit jantung koroner di Indonesia tahun 2013 dengan usia $\geq 15$ tahun sebesar $0,5 \%$ atau diperkirakan sekitar 883.447 orang, sedangkan berdasarkan diagnosis gejala $1,5 \%$ atau diperkirakan sekitar 2.650 .340 orang. Berdasarkan diagnosis dokter, estimasi jumlah penderita penyakit jantung koroner terbanyak terdapat di Provinsi Jawa Barat sebanyak 160.812 orang $(0,5 \%)$. Di Provinsi Sulawesi Utara sendiri berdasarkan diagnosis dokter sebanyak 11.892 orang $(0,7 \%)$ dan berdasarkan gejala sebanyak 28.880 orang $(1,7 \%){ }^{3}$

Penyakit jantung koroner terjadi oleh karena adanya ateroklerosis. Aterosklerosis merupakan keadaan yang dapat timbul dari keabnormalan peningkatan kadar kolesterol yang dapat mengakibatkan akumulasi patologik dalam dinding pembuluh darah, oleh karena terbentuknya sumbatan yaitu berupa plak, dimana secara bertahap dapat menimbulkan rentetan kerusakan. Ketika plak terbentuk di arteri, plak tersebut mempersempit arteri dan mengurangi aliran darah ke otot jantung, mempermudah terbentuknya bekuan dalam arteri, sehingga terjadi penebalan dan kekakuan pada arteri. $^{4}$

Kolesterol merupakan lemak netral yang diperlukan untuk sintesis senyawasenyawa penting dalam tubuh seperti hormon dan asam kolat di hati. Kolesterol terdapat di jaringan dan plasma sebagai kolesterol bebas atau dalam bentuk simpanan. Di dalam plasma, kedua bentuk tersebut diangkut oleh lipoprotein. Empat kelompok utama lipoprotein yaitu kilomikron, Very Low Density Lipoprotein (VLDL), Low Density Lipoprotein (LDL), High Density Lipoprotein (HDL). Setiap jenis lipoprotein memiliki fungsi yang berbeda dan dipecah serta dibuang dengan cara yang sedikit berbeda.,

Beberapa faktor yang dapat meningkatkan kadar lemak tertentu yaitu riwayat keluarga dengan hiperlipidemia, obesitas, diet kaya lemak, penggunaan alkohol, merokok serta kurang melakukan olah raga dan aktivitas fisik. Faktor-faktor ini merupakan indikator pencetus timbulnya Penyakit Jantung Koroner $(\mathrm{PJK}){ }^{7}$

Intensitas akivitas seseorang berpengaruh terhadap kadar lemak dalam tubuh. Berat ringannya beban kerja sangat dipengaruhi oleh jenis aktivitas. Dalam sebuah penelitian tentang Perbedaan Aktivitas Fisik Pekerja Bagian Administrasi dan Produksi PT. Pupuk Kuning Cikampek yang dilakukan oleh Aziza tahun 2014, menjelaskan bahwa pekerja kantor dengan beban kerja berat memiliki kadar kolesterol yang lebih rendah dibandingkan pekerja kantor dengan beban kerja yang lebih ringan. Pekerja kantor dengan beban kerja ringan mempunyai risiko mengalami peningkatan kadar kolesterol.

Aktivitas fisik berupa olahraga dan kegiatan harian yang dilakukan secara rutin dapat meningkatkan konsentrasi HDL dan bermanfaat untuk mencegah timbunan lemak di dinding pembuluh darah. Aktivitas yang ringan cenderung mengakibatkan penimbunan lemak pada arteri sehingga terjadi aterosklerosis yang merupakan faktor risiko terhadap Penyakit Jantung Koroner (PJK). ${ }^{8}$

Tujuan dari penelitian ini untuk mengetahui gambaran kadar kolesterol total pada pekerja kantor.

\section{METODE PENELITIAN}

Penelitian yang digunakan bersifat deskriptif dengan pendekatan cross sectional. Penelitian ini dilaksanakan sepanjang bulan Agustus hingga Desember 2016 di PT. Bank Sulut Go Manado. Sampel dalam penelitian ini berjumlah 52 orang yang sesuai kriteria dan bersedia menjadi responden. Metode pemilihan sampel menggunakan cara total sampling. 
Pemeriksaan kadar kolesterol total darah diambil melalui darah vena (fossa cubiti) dimana responden puasa 10-12 jam. Sampel darah yang diperoleh dibawa ke laboratorium untuk memperoleh hasil yang lebih lanjut.

\section{HASIL PENELITIAN}

Pada penelitian yang dilakukan berdasarkan jenis kelamin, ditemukan perempuan merupakan responden terbanyak yang berpartisipasi dalam penelitian ini, yaitu sebanyak 27 orang $(51,92 \%)$, dan (Tabel 1). Distribusi responden menurut usia (Tabel 2), menunjukkan bahwa responden dengan usia <45 tahun merupakan responden terbanyak $(76,92 \%)$.

Tabel 1. Distribusi responden menurut jenis kelamin

\begin{tabular}{ccc}
\hline Jenis Kelamin & $(\mathbf{n})$ & $(\boldsymbol{\%})$ \\
\hline Laki-laki & 25 & 48,08 \\
Perempuan & 27 & 51,92 \\
Total & 52 & 100 \\
\hline
\end{tabular}

Tabel 2. Distribusi responden menurut usia

\begin{tabular}{ccc}
\hline Usia & $(\mathbf{n})$ & $\mathbf{( \% )}$ \\
\hline$\geq 45$ thn & 12 & 23,08 \\
$<45$ thn & 40 & 76,92 \\
Jumlah & 52 & 100 \\
\hline
\end{tabular}

Data kadar kolesterol total darah penelitian ini menunjukkan bahwa responden dengan kadar kolesterol normal $(<200 \mathrm{mg} / \mathrm{dL})$ dan responden dengan kadar kolesterol tinggi memiliki jumlah responden yang sama yaitu sebanyak 26 orang dengan persentase sebesar 50\% (Tabel 3). Hasil pengukuran kadar kolesterol total darah didapatkan nilai ratarata yaitu $198 \mathrm{mg} / \mathrm{dL}$, nilai median 201 $\mathrm{mg} / \mathrm{dL}$, nilai modus $214 \mathrm{mg} / \mathrm{dL}$, nilai minimal $143 \mathrm{mg} / \mathrm{dL}$, nilai maksimal 273 $\mathrm{mg} / \mathrm{dL}$, dan standar deviasi 29,22.

Data distribusi jenis kelamin terhadap kadar kolesterol (Tabel 4) menunjukkan bahwa perempuan dengan kadar kolesterol normal merupakan jumlah responden terbanyak yaitu 14 orang (26,92\%).
Sedangkan, pada hasil penelitian responden dengan kadar kolesterol tinggi menunjukkan bahwa jenis kelamin perempuan dan laki-laki memiliki hasil yang sebanding yaitu sebanyak 13 orang $(50 \%)$.

Tabel 3. Distribusi responden berdasarkan kadar kolesterol dalam darah

\begin{tabular}{ccc}
\hline $\begin{array}{c}\text { Kadar kolesterol } \\
\text { total }(\mathbf{m g} / \mathbf{d L})\end{array}$ & $(\mathbf{n})$ & $\mathbf{( \% )}$ \\
\hline$<200$ & 26 & 50 \\
$\geq 200$ & 26 & 50 \\
Total & 52 & 100 \\
\hline
\end{tabular}

Tabel 4. Distribusi jenis kelamin terhadap kadar kolesterol total

\begin{tabular}{cccc}
\hline $\begin{array}{c}\text { Jenis } \\
\text { Kelamin }\end{array}$ & \multicolumn{2}{c}{$\begin{array}{c}\text { Kadar Kolesterol } \\
\text { total }(\mathbf{m g} / \mathbf{d L})\end{array}$} & $\mathbf{N}$ \\
& $<200$ & $\geq 200$ & \\
\hline Laki-laki & 12 & 13 & 25 \\
Perempuan & 14 & 13 & 27 \\
Total & 26 & 26 & 52 \\
\hline
\end{tabular}

\section{BAHASAN}

Berdasarkan dari hasil penelitian, terdapat sebanyak 26 orang responden (50\%) dengan kadar kolesterol total darah normal dan 26 responden dengan kadar kolesterol total darah tinggi. Hal ini sesuai dengan penelitian sebelumnya yang dilakukan oleh Bantas tahun 2012 pada 198 pekerja kawasan industri suku cadang dimana menunjukkan hasil yang hampir sebanding antara responden dengan kadar kolesterol normal $(20,00 \%)$ dan responden dengan kadar kolesterol tinggi $(21,1 \%){ }^{10}$

Berbeda dengan penelitian sebelumnya yang dilakukan oleh Zahrawardani tahun 2012 di Semarang pada 128 responden pekerja administrasi, didapatkan responden dengan kadar kolesterol total normal merupakan responden terbanyak yang berjumlah 69 orang $(53,90 \%)$. $^{11}$

Peningkatan kadar kolesterol dalam darah pada 26 responden dalam penelitian dapat disebabkan kerena beberapa faktor yang dapat memengaruhi konsentrasi kolesterol plasma, yaitu jumlah kolesterol 
yang dicerna setiap hari, diet lemak yang sangat jenuh, serta penurunan kadar insulin dan hormon tiroid. ${ }^{12}$

Riwayat tekanan darah tinggi, merokok, obesitas (terutama obesitas abdominal), kurang berolah raga, kebiasaan minum air putih yang kurang, kebiasaan minum kopi dan konsumsi alkohol berlebih, serta usia merupakan faktor-faktor risiko peningkatan kadar kolesterol total dalam darah. Jenis kelamin juga disebutkan sebagai salah satu faktor risiko peningkatan kadar kolesterol total oleh karena adanya suatu sistem kerja hormon. ${ }^{5}$

Pada penelitian dengan judul Kolesterol Total Darah Pada Orang Dewasa Indonesia yang dilakukan oleh Morgarita dkk pada tahun 2014 dengan 51 responden, menjelaskan adanya gambaran risiko hiperkolesterolemia pada jenis kelamin laki-laki $(70,6 \%)$ lebih tinggi dibandingkan perempuan $(29,4 \%) .{ }^{13}$ Penelitian dengan gambaran yang sama dilakukan oleh Zahrawardani tahun 2012 pada 128 responden pekerja administrasi penelitian didapatkan jenis kelamin laki-laki memiliki kadar kolesterol tinggi merupakan responden terbanyak $(68,80 \%) .{ }^{10}$

Kadar kolesterol total dalam darah yang tinggi merupakan faktor pemicu tingginya angka mortalitas dan morbiditas yang disebabkan oleh adanya gangguan jantung dan pembuluh darah. Berdasarkan prevalensi laki-laki dan perempuan, lakilaki dengan kadar memiliki risiko yang lebih tinggi untuk mengalami penyakit jantung dan pembuluh darah. Menurut Darmojo risiko laki-laki untuk terkena penyakit jantung dan pembuluh darah melampaui risiko pada perempuan setelah usia remaja sampai usia sekitar 50 tahun ke atas. Pada tahun-tahun pre-menopause perempuan dilindungi oleh hormon estrogen yang tidak dimiliki oleh kaum laki-laki. Hormon estrogen dapat mencegah terbentuknya plak pada arteri dengan menaikkan kadar HDL dan menurunkan kadar LDL. ${ }^{14}$

Estrogen berperan dalam menjaga tingkat HDL agar tetap tinggi dan LDL tetap rendah. $^{15}$ Namun setelah masa menopause lewat kadar estrogen pada perempuan menurun. Oleh karena itulah perempuan yang sudah mengalami menopause memiliki risiko yang lebih tinggi dibandingkan sebelum menopause. Dengan demikian hormon estrogen dianggap sebagai proteksi terhadap terjadinya peningkatan kadar kolesterol yang berlebih. ${ }^{16}$

Selain jenis kelamin, usia juga merupakan salah satu faktor yang dapat mempengaruhi peningkatan kadar kolesterol total darah. Seperti penjelasan diatas mengatakan adanya hubungan dengan kerja hormon estrogen pada perempuan yang berusia $<55$ tahun, dimana estrogen berguna untuk menjaga kadar HDL tetap tinggi dan LDL tetap rendah, sedangkan setelah menopause dengan usia sekitar >55 tahun kadar estrogen menurun drastis yang mengakibatkan faktor risiko peningkatan kadar kolesterol meningkat pada perempuan. Pada penelitian Listiana dan Purbosari terhadap 30 orang responden yang memeriksakan kadar kolesterol pada bulan Mei-Juni di rumah sakit Bhayangkara Porong didapatkan rata-rata kadar kolesterol sebanyak 231,90 $\mathrm{mg} / \mathrm{dL}$ dan rata-rata umur 37 tahun. ${ }^{17}$

Pada penelitian Zahrawardani (2012) dari 128 sampel pekerja administrasi penelitian, responden yang memiliki kadar kolesterol $>200 \mathrm{mg} / \mathrm{dL}$ dengan usia $\geq 45$ tahun lebih banyak yaitu 107 responden $(83,60 \%)$ dibandingkan responden dengan usia $<45$ tahun $(16,40 \%) .{ }^{10}$ Semakin tua usia maka semakin besar kemungkinan timbulnya karat yang menempel di dinding dan menyebabkan mengganggu aliran air yang melewatinya. Oleh karena itu, usia juga merupakan salah satu faktor risiko terjadinya peningkatan kolesterol dalam darah.

Olahraga dan aktifitas fisik juga dapat berpengaruh pada profil lipid darah. Berdasarkan penelitian yang dilakukan oleh Galih Tri Utomo dkk pada tahun 2012 pada siswa sekolah dasar terjadi penurunan berat badan, persen lemak tubuh dan kadar kolesterol darah yang disebabkan oleh meningkatnya aktifitas fisik pada sampel 
yang semula melakukan olahraga hanya seminggu sekali pada waktu pelajaran olahraga di sekolahnya menjadi 3 kali seminggu dengan intensitas rendah. Dengan meningkatnya aktifitas fisik tersebut, menyebabkan terbakarnya cadangan lemak tubuh untuk memenuhi kebutuhan kalori tubuh pada saat latihan senam aerobik. Sedangkan aktivitas fisik yang rendah dan kurang berolah raga yang ditambah dengan asupan makanan yang berlebih merupakan faktor penimbunan lemak pada tubuh yang dapat mengakibatkan tingginya kadar kolesterol dalam plasma. ${ }^{17}$

Kelemahan dari penelitian ini, pertama, jumlah responden yang terbatas, sehingga perlu dilakukan penelitian lebih lanjut dengan jumlah responden yang lebih banyak. Kedua, tidak dilakukan pengambilan data food record, sehingga tidak ada data tentang jumlah kolesterol eksogen yang dikonsumsi setiap hari.

\section{SIMPULAN DAN SARAN}

Dari hasil penelitian dapat disimpulkan bahwa terdapat jumlah seimbang antara responden dengan kadar kolesterol darah normal dan responden dengan kadar kolesterol diatas normal.

Berdasarkan hasil penelitian, dapat disarankan beberapa hal yaitu, bagi responden yang memiliki kadar kolesterol total dalam batas normal dianjurkan untuk tetap menjaga pola makan tetap seimbang, responden dengan kadar kolesterol total tinggi dianjurkan untuk menurunkan kadar kolesterol total darah menjadi normal dan untuk penelitian lebih lanjut perlu penambahan terhadap jumlah responden, penelitian analitik, penambahan variabel dan data food record.

\section{DAFTAR PUSTAKA}

1. World Health Organization. Cardiovascular Disease. Available from: http://www.who.int/mediacentre/facts heets/fs317/en/. 2012. Accesed on: August $29^{\text {th }} 2016$.

2. Melanie N, Nick T. Mortality. In: Susanne L, O'Kelly S, editors. European
Cardiovascular Disease Statistics. Belgium: European Heart Network and European Society of Cardiology, 2012; p.10-34.

3. Departemen Kesehatan. Situasi kesehatan jantung. Available from: www.depkes.go.id/situasijantung/. 2013. Accesed on: August $29^{\text {th }} 2016$.

4. Brody, T. Nuritional Biochemistry. Academic Press Inc. San Diego; 1999; p.249-93.

5. Botham KM, Mayes PA. Sintesis, transpor, \& ekskresi kolesterol. Dalam: Murray RK, Granner DK, Mayes PA, Rodwell VW, editors. Biokimia Harper. Edisi ke 27. Pendit BU, alih bahasa. Wulandari $\mathrm{N}$, editor edisi Indonesia. Jakarta: EGC, 2006; p.239-49.

6. Almatsier, S. Prinsip Dasar Ilmu Gizi. Jakarta: PT. Gramedia Pustaka Umum; 2004; p.51-74.

7. UPT-Balai Informasi Tentang Teknologi LIPI. Kolesterol tinggi pangan dan kesehatan. 2009.

8. Aziza Z. Perbedaan Aktivitas Fisik Intensitas Berat, Asupan Zat Gizi Makro, Persentase Lemak Tubuh, dan Lingkar Perut Antara Pekerja Bagian Produksi dan Administrasi PT. Pupuk Kujang Cikampek. [thesis]. Semarang: Fakultas Kedokteran Universitas Diponegoro. 2014.

9. Bantas. Risiko Hiperkolesterolemia Pada Pekerja di Kawasan Industri. [Thesis]. Jakarta: Fakultas Kedokteran Universitas Indonesia. 2012.

10.Zahrawardani D. Analisis Faktor Resiko Kejadian Jantung Koroner di RSUD Dr. Kaswardi Semarang. [thesis]. Semarang: Fakultas Kedokteran Universitas Muhammadiyah. 2012.

11.Bantas. Risiko Hiperkolesterolemia Pada Pekerja di Kawasan Industri. [Thesis]. Jakarta: Fakultas Kedokteran Universitas Indonesia. 2012.

12.Guyton AC, Hall JE. Buku Ajar Fisiologi Kedokteran. Edisi 11. Rachman LY, Hartanto H, Novrianti A, Wulandari $\mathrm{N}$, alih bahasa Indonesia. Jakarta: EGC, 2006; p.882-94.

13.Morgarita Y, Princen, Andi, Rumawas ME, Kidarsa VB, Sutrisna B. Kadar 
Oktavia, Tiho, Kaligis: Gambaran kadar kolesterol...

Kolesterol Total Darah Orang Dewasa Indonesia. [thesis]. Jakarta: Fakultas Kedokteran Universitas Tarumanegara. 2014.

14. Boedi D, Hadi M. Buku Ajar Geriatri. Balai Penerbit FKUI. Jakarta: 1999; p.242.

15.Bull E, Morrell J. Simple Guides Cholesterol. Edisi ke-1. Jakata: Erlangga, 2007; p.3-22.

16. Brown CT. Penyakit Aterosklerotik Koroner. Dalam: Hartanto H, Susi N, Wulansari P, Mahanani DA alih bahasa Indonesia. Patofisiologi
Konsep Klinis Proses-Proses Penyakit. Edisi ke-6. Jakarta: EGC, 2006; p.578-93.

17.Listina L, Purbosari TY. Kadar Kolesterol Total Pada Usia 25-60 Tahun. Jakarta: Fakultas Kedokteran Universitas Indonesia. 2013.

18.Utomo GT, Junaidi S, Rahayu S. Latihan Senam Aerobik untuk Menurunkan Berat Badan, Lemak dan Kolesterol. [Thesis]. Semarang: Fakultas Ilmu Keolahragaan Universitas Negeri Semarang. 2012. 